\title{
Low Redox Potential Promotes Sulphide- and Light-dependent Hydrogen Evolution in Oscillatoria limnetica
}

\author{
By SHIMSHON BELKIN* AND ETANA PADAN \\ Division of Microbial and Molecular Ecology, Institute of Life Sciences, Hebrew University, Givat \\ Ram, Jerusalem 91904, Israel
}

(Received 19 April 1983; revised 25 May 1983)

\begin{abstract}
Anoxygenic photosynthetic electron transport from sulphide, culminating in either $\mathrm{H}_{2}$ evolution or $\mathrm{CO}_{2}$ photoassimilation, was shown to include the segment from plastoquinone to ferredoxin in the cyanobacterium Oscillatoria limnetica. Both sulphide-dependent $\mathrm{H}_{2}$ evolution and $\mathrm{CO}_{2}$ photoassimilation were inhibited by plastoquinone analogues. In the former reaction, the block was bypassed by reduced $N, N, N^{\prime}, N^{\prime}$-tetramethyl-p-phenylenediamine (TMPD). The link between this segment of electron transport and the hydrogenase enzyme was shown to limit the rate of sulphide-dependent $\mathrm{H}_{2}$ evolution. The rate of flow of electrons through this pathway was lower than would be expected either from the amounts of available enzyme, as measured by the in vitro oxidation of reduced methyl viologen, or from rates of electron transport to $\mathrm{CO}_{2}$ photoassimilation. When the strong reductant sodium dithionite was added to intact cells, the resulting low redox potential significantly improved photosynthetic sulphide-dependent $\mathrm{H}_{2}$ evolution. Hydrogenase activity in cell free extracts was similarly affected by dithionite. It is suggested that ambient redox potential controls electron flow through the hydrogenase, so that surplus reducing power is removed via $\mathrm{H}_{2}$ evolution.
\end{abstract}

\section{INTRODUCTION}

Light-dependent utilization of sulphide electrons by the cyanobacterium Oscillatoria limnetica requires a preliminary induction period in the presence of sulphide (Cohen et al., 1975 a; Belkin $\&$ Padan, $1978 a, b)$. Low redox potential shortens the length of this adaptation. In the presence of dithionite (10 mM) the lag at pH 6.8 is eliminated (Belkin \& Padan, 1983). Once adaptation is complete and sulphide electrons enter the photosynthetic electron transport chain, they can be channelled to three different acceptors: (a) $\mathrm{CO}_{2}$, when a normal mode of anoxygenic photosynthesis takes place (Cohen et al., 1975a, b; Oren et al., 1977, 1979; Oren \& Padan, 1978; Padan, 1979); (b) protons, when no $\mathrm{CO}_{2}$ is available or when $\mathrm{CO}_{2}$ fixation is blocked (Belkin \& Padan, 1978a,b); (c) $\mathrm{N}_{2}$, when no combined nitrogen is present (Belkin et al., 1982).

The anoxygenic $\mathrm{CO}_{2}$ photoassimilation reaction is unaffected by DCMU, the photosystem II inhibitor (Cohen et al., 1975a) and inhibited by the ferredoxin-blocking agent DSPD (Belkin \& Padan, 1978b). The sulphide-dependent $\mathrm{H}_{2}$ evolution reaction is mediated by an hydrogenase (Belkin \& Padan, 1978 $a, b$ ) and like the former reaction it is insensitive to DCMU and inhibited by DSPD. Both systems thus share photosynthetic electron transport driven by photosystem I. This communication deals with this electron transport segment and its linkage to the hydrogenase for $\mathrm{H}_{2}$ evolution.

\footnotetext{
Abbreviations: DBMIB, 2,5-dibromo-3-methyl-6-isopropyl-p-benzoquinone; DCMU, 3-(3,4-dichlorophenyl)1,1-dimethylurea; DNP-INT, 2,4-dinitrophenyl ether of 2-iodo-4-nitrothymol; DSPD, disalicylidenepropanediamine; FCCP, carbonyl cyanide $p$-trifluoromethoxyphenylhydrazone; MES, 2- $(N$-morpholino)ethanesulphonic acid; HEPES, $N$-2-hydroxyethylpiperazine- $N$ '-2-ethanesulphonic acid; TAPS, tris(hydroxymethyl)methylaminopropanesulphonic acid; TMPD, $N, N, N^{\prime}, N^{\prime}$-tetramethyl-p-phenylenediamine.
} 
Light-driven $\mathrm{H}_{2}$ production is basically an energy-wasteful process. However, under certain conditions, it can be utilized to rid the cells of excess reducing power, as suggested by Hillmer \& Gest (1977). To investigate the influence of low redox potential on $\mathrm{H}_{2}$ evolution in $O$. limnetica, we studied the effect of the strong reductant sodium dithionite on both intact cells and cell-free extracts. The rate-limiting step for sulphide-dependent $\mathrm{H}_{2}$ evolution was the activity of the hydrogenase. This activity was significantly improved by the low redox potential supplied by dithionite.

\section{METHODS}

Growth of cyanobacterium. Oscillatoria limnetica (Cohen et al., 1975a) was grown aerobically or anaerobically as previously described (Oren et al., 1977; Oren \& Padan, 1978). Exponential growth phase, in both cases, lasted 5$6 \mathrm{~d}$.

Preparation of cells for experiments. Cells from exponential phase, aerobically grown cultures were harvested, washed and resuspended (10-20 $\mu \mathrm{g}$ chlorophyll $\left.a \mathrm{ml}^{-1}\right)$ in an anaerobic growth medium lacking $\mathrm{Na}_{2} \mathrm{CO}_{3}$ and containing $10 \mu \mathrm{M}$-DCMU. The medium was buffered with $25 \mathrm{mM}-\mathrm{HEPES}$ for the $\mathrm{pH}$ range $7 \cdot 0-8 \cdot 2$, and $25 \mathrm{~mm}-$ MES or TAPS were used for lower and higher $\mathrm{pH}$, respectively. Anaerobically grown cultures were similarly treated after precipitation of the sulphur deposited during anaerobic growth by a low-speed centrifugation $(1000 \mathrm{~g})$ for $15 \mathrm{~s}$.

Cell-free extracts. Cells were washed, resuspended $\left(50 \mu \mathrm{g} \mathrm{chl} . a \mathrm{ml}^{-1}\right)$ in $10 \mathrm{~mm}$-HEPES buffer, $\mathrm{pH} 8 \cdot 0$, and preincubated for $5 \mathrm{~min}$ in the dark at $35^{\circ} \mathrm{C}$ under $\mathrm{N}_{2}$; lysozyme was then added to a final concentration of $1 \mathrm{mg} \mathrm{ml}^{-1}$. Cell disruption was followed microscopically and by release of phycocyanin into the medium, as measured at $A_{620}$. Complete cell burst was evident after $30-45 \mathrm{~min}$ incubation.

$\mathrm{H}_{2}$ evolution. Serum bottles $(15 \mathrm{ml})$ containing $2 \mathrm{ml}$ of intact or disrupted cell suspension were sealed with serum stoppers, flushed with $\mathrm{N}_{2}$ for 20 min to obtain anaerobic conditions and incubated at $35^{\circ} \mathrm{C}$ with shaking, with or without illumination $\left(2.5 \mathrm{~mJ} \mathrm{~cm} \mathrm{~cm}^{-2} \mathrm{~s}^{-1}\right)$. For induction, $3.5 \mathrm{mM}-\mathrm{Na}_{2} \mathrm{~S}$ was added and the cells were preincubated for $3 \mathrm{~h}$ in the light. They were then washed and resuspended in the $\mathrm{N}_{2}$-flushed medium lacking $\mathrm{Na}_{2} \mathrm{~S}$. All additions and withdrawals were made anaerobically with syringes after the $\mathrm{N}_{2}$ flushing. $\mathrm{H}_{2}$ was determined in gas samples as previously described (Belkin \& Padan, $1978 a$ ). $\mathrm{H}_{2}$ evolution from reduced methyl viologen was assayed in cell-free preparations in the dark, containing, in $2 \mathrm{ml}, 25 \mu \mathrm{g}$ chlorophyll $a \mathrm{ml}^{-1}$, with $2.5 \mathrm{~mm}$-methyl viologen reduced by $10 \mathrm{~mm}$-sodium dithionite, in $20 \mathrm{~mm}$-HEPES, pH $8.0\left(35^{\circ} \mathrm{C}\right)$.

Redox titrations. Determination of redox potential was carried out in an anaerobic water-jacketed $\left(35^{\circ} \mathrm{C}\right)$ chamber, using a platinum electrode (Ingold, type 10-805-3000) with a calomel reference electrode (Radiometer, type K401). Both electrodes were connected to a $\mathrm{pH}$ meter (Radiometer model 26). For simultaneous $\mathrm{pH}$ monitoring a combined pH electrode (El-Hama, type 1160-400) was also inserted in the assay chamber and connected to an El-Hama PBS730 pH meter; samples of sodium dithionite (200 mM, in anaerobic $250 \mathrm{mM}$-MES or HEPES buffer) were added stepwise to $20 \mathrm{ml}$ of the standard reaction medium which included $3 \cdot 5 \mathrm{mM}-\mathrm{Na}_{2} \mathrm{~S}$. Redox potential was recorded after each addition. $\mathrm{H}_{2}$ evolution was determined in gas samples with or without illumination $\left(2.5 \mathrm{~mJ} \mathrm{~cm}^{-2} \mathrm{~s}^{-1}\right)$.

$\mathrm{CO}_{2}$ photoassimilation. This was determined in intact $\mathrm{O}$. limnetica cells under identical conditions to the $\mathrm{H}_{2}$ evolution assay, but with $\mathrm{NaH}^{14} \mathrm{CO}_{3}$ injected after the $\mathrm{N}_{2}$ flushing to a final concentration of $14 \mathrm{~mm}$ and a specific activity of $0.06 \mathrm{Ci} \mathrm{mol}^{-1}\left(2.2 \mathrm{GBq} \mathrm{mol}^{-1}\right)$. The radioactivity incorporated into the cells was determined as previously described (Oren et al., 1977).

Chlorophyll and sulphide. There were determined according to previously described methods (Mackinney, 1941; Trüper \& Schlegel, 1964).

Chemicals. Methyl viologen, HEPES, MES, TAPS, and TMPD were purchased from Sigma and $\mathrm{NaH}^{14} \mathrm{CO}_{3}$ from Amersham. DCMU and FCCP were obtained from Dupont, Wilmington, Delaware, U.S.A. DBMIB and DNP-INT were a gift from Professor M. Avron and Dr Y. Shachak of the Weizmann Institute of Science, Rehovot. $\mathrm{Na}_{2} \mathrm{~S} .9 \mathrm{H}_{2} \mathrm{O}$ was from $\mathrm{BDH}$ and sodium dithionite from Riedle, Seelze-Hannover, F.R.G.

\section{RESULTS}

The sulphide-dependent electron transport shared by $\mathrm{H}_{2}$ evolution and $\mathrm{CO}_{2}$ photoassimilation

The effect of the plastoquinone antagonist DBMIB on sulphide-dependent $\mathrm{H}_{2}$ evolution was examined. Activity was inhibited by $75-80 \%$ by $2 \times 10^{-5}$ M-DBMIB (Table 1 ), localizing the quinone in the electron transport sequence from sulphide. The electron carrier TMPD, which, when reduced, donates electrons to plastocyanin (Trebst \& Reimer, 1977) and therefore bypasses the DBMIB-blocked site, restored activity to the original rate. Similar results were 
Table 1. Effect of quinone analogues on sulphide-dependent hydrogen evolution

Two-d-old cells from an anaerobically grown $O$. limnetica culture were washed and resuspended $(14 \mu \mathrm{g}$ chl. $a \mathrm{ml}^{-1}$ ) in $2 \mathrm{ml}$ of the anaerobic growth medium in the absence of $\mathrm{CO}_{2}$, and in the presence of $10 \mu \mathrm{M}$-DCMU and $25 \mu \mathrm{M}$-HEPES, pH 7.5. Following a $20 \mathrm{~min}$ flushing with $\mathrm{N}_{2}$ and an anaerobic addition of $3 \mathrm{mM}-\mathrm{Na}_{2} \mathrm{~S}, \mathrm{H}_{2}$ evolution was assayed in the light.

\section{Additions}

(M)

\begin{tabular}{|c|c|}
\hline \multicolumn{2}{|c|}{$\mathrm{H}_{2}$ evolution rate } \\
\hline$\mu \mathrm{mol}(\mathrm{mg} \text { chl. } a)^{-1} \mathrm{~h}^{-1}$ & $\%$ \\
\hline $12 \cdot 0$ & 100 \\
\hline $2 \cdot 7$ & 23 \\
\hline $12 \cdot 4$ & 104 \\
\hline $7 \cdot 1$ & 59 \\
\hline $10 \cdot 8$ & 90 \\
\hline
\end{tabular}

obtained with another plastoquinone inhibitor, DNP-INT, (Trebst et al., 1978) (Table 1). Although the results described in Table 1 refer to experiments conducted with anaerobically grown cells, similar results were obtained with cells induced with sulphide for only $3 \mathrm{~h}$. Similar to its effect on $\mathrm{H}_{2}$ evolution, DBMIB inhibited sulphide-dependent $\mathrm{CO}_{2}$ photoassimilation by $80 \%$ (not shown). Both reactions were previously shown to be inhibited by the ferredoxin blocking agent DSPD (Belkin \& Padan, 1978b). Hence it is suggested that the segment of the photosynthetic electron transport chain shared by both sulphide-dependent $\mathrm{H}_{2}$ evolution and $\mathrm{CO}_{2}$ photoassimilation includes the quinone, and proceeds through photosystem I up to ferredoxin.

\section{The hydrogenase activity limits the rate of sulphide-dependent hydrogen evolution}

The electrons destined for $\mathbf{H}_{2}$ evolution exhibited much slower transport rates than those channelled to $\mathrm{CO}_{2}$ fixation. After a $3 \mathrm{~h}$ induction, only $2.4 \mu$ equiv. $\mathrm{e}^{-}(\mathrm{mg} \text { chl. } a)^{-1} \mathrm{~h}^{-1}$ were expelled as molecular $\mathrm{H}_{2}$, whereas the rate of electron transfer to $\mathrm{CO}_{2}$ was $280 \mu$ equiv. $\mathrm{e}^{-}$ (mg chl. $a)^{-1} \mathrm{~h}^{-1}$. Similar results were obtained with anaerobically grown cells, although in the latter system both activities markedly increased. After $3 \mathrm{~d}$ anaerobic growth, anoxygenic $\mathrm{CO}_{2}$ photoassimilation rates increased twofold to $530 \mu$ equiv. $\mathrm{e}^{-}(\mathrm{mg} \mathrm{chl} . a)^{-1} \mathrm{~h}^{-1}$, whereas rates of electron transfer to $\mathrm{H}_{2}$ evolution increased more than 12-fold to $30 \mu$ equiv. $\mathrm{e}^{-}(\mathrm{mg} \text { chl. } a)^{-1} \mathrm{~h}^{-1}$. Even after this dramatic increase, however, nearly $95 \%$ of the electron transfer potential exhibited by the $\mathrm{CO}_{2}$ photoassimilation reaction was not utilized for $\mathrm{H}_{2}$ evolution. It was concluded that a rate-limiting step exists in the electron pathway from sulphide to $\mathrm{H}_{2}$ and that this must be due to factors located beyond the common segment shared by both reactions, namely the specific electron pathway diverged to hydrogenase, and/or hydrogenase itself.

Hydrogenase potential activity can be estimated in cell-free preparations by measuring dark $\mathrm{H}_{2}$ evolution from dithionite-reduced methyl viologen. After a $3 \mathrm{~h}$ induction period, the amount of enzyme present in $O$. limnetica cells maintained a rate of $\mathrm{H}_{2}$ evolution equivalent to 18.6 $\mu$ equiv. $\mathrm{e}^{-}(\mathrm{mg} \text { chl. } a)^{-1} \mathrm{~h}^{-1}$, which is nearly eight times higher than the light- and sulphidedependent reaction via the electron transport chain. This pattern did not change significantly during anaerobic growth, since both the enzyme level and the rate of photosynthetic $\mathrm{H}_{2}$ evolution increased similarly. The total hydrogenase activity was then $140 \mu \mathrm{mol} \mathrm{H}_{2}$ evolved (mg chl. a) ${ }^{-1} \mathrm{~h}^{-1}$, which was five times higher than the photosynthetic reaction (Fig. 1). Thus the actual light-dependent expression of the enzyme comprised, at best, only $20 \%$ of the total potential activity of the enzyme. It is thus suggested that the rate-limiting factor in sulphidedependent $\mathrm{H}_{2}$ evolution is not the total hydrogenase level, but rather its in vivo activity.

\section{Low redox potential modulates hydrogenase activity}

Dithionite cannot serve as an electron donor for photosynthetic reactions in aerobically or anaerobically grown $O$. limnetica (Oren, 1978 and Fig. 2). However, when it was added to cells, induced for $3 \mathrm{~h}$ in the presence of sulphide, a fivefold increase from 1 to $5 \mu \mathrm{mol} \mathrm{H}_{2}$ (mg chl. 


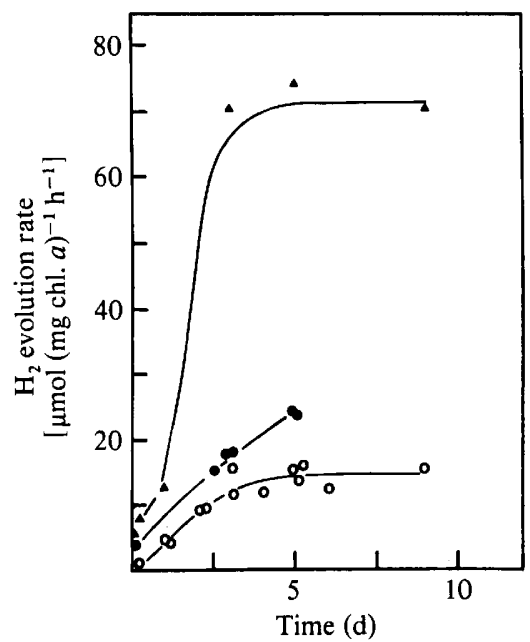

Fig. 1.

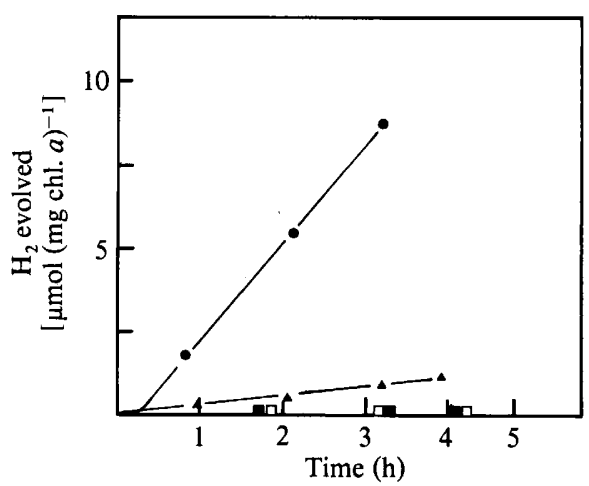

Fig. 2

Fig. 1. $\mathrm{H}_{2}$ evolution during anaerobic growth in the absence $(O)$ or presence $(O)$ of 10 mM-sodium dithionite in the light at $\mathrm{pH} 8.0$, and dark $\mathrm{H}_{2}$ evolution by disrupted cells $(\Delta)$ in the presence of $2.5 \mathrm{~mm}$ methyl viologen reduced by $10 \mathrm{~mm}$-sodium dithionite.

Fig. 2. Acceleration by sodium dithionite of sulphide-dependent $\mathrm{H}_{2}$ evolution in $3 \mathrm{~h}$ induced $O$. limnetica cells. The pH was 7.3 and the following additions were made at zero time: $\square$, none; $\square$, sodium dithionite $(10 \mathrm{mM}) ; \Delta, \mathrm{Na}_{2} \mathrm{~S}(3.5 \mathrm{mM}) ; \boldsymbol{O}, \mathrm{Na}_{2} \mathrm{~S}$ and sodium dithionite.

$a)^{-1} \mathrm{~h}^{-1}$ occurred in light- and sulphide-dependent $\mathrm{H}_{2}$ evolution. Although to a lesser extent, even the already enhanced rates of $\mathrm{H}_{2}$ evolution of anaerobically grown cells were significantly increased by the addition of sodium dithionite to the reaction mixture (Fig. 1). In all cases, the light saturation behaviour of $\mathrm{H}_{2}$ evolution did not change (not shown), and the reactions were carried out under light-saturating conditions.

The effect of dithionite on the rate of $\mathrm{H}_{2}$ evolution was $\mathrm{pH}$ independent. In the presence of $10 \mathrm{mM}$ of this compound, a constant maximal rate of $6 \mu \mathrm{mol} \mathrm{H}_{2}(\mathrm{mg} \mathrm{chl} . a)^{-1} \mathrm{~h}^{-1}$ was observed throughout the $\mathrm{pH}$ range $6 \cdot 5-9 \cdot 0$. When the reaction was measured in the presence of sulphide alone, however, the same high rates were attained only at $\mathrm{pH}$ values greater than $8 \cdot 2$; activity decreased to $4 \mu \mathrm{mol} \mathrm{H}_{2}(\mathrm{mg} \mathrm{chl} . a)^{-1} \mathrm{~h}^{-1}$ at $\mathrm{pH} 8.0$ and was virtually zero at $\mathrm{pH} 7 \cdot 1$.

Dithionite has a very low redox potential of about $-450 \mathrm{mV}$ (Van Dijk \& Veeger, 1981), which may be the factor responsible for its effect on $\mathrm{H}_{2}$ evolution. Sulphite, the oxidized decomposition product of dithionite, had no significant effect on the reaction. To further test the effect of low redox potential, cells were exposed to different dithionite concentrations at two $\mathrm{pH}$ values, and both ambient redox potentials and $\mathrm{H}_{2}$ evolution were measured. At the two $\mathrm{pH}$ values tested, 6.6 (Fig. $3 a$ ) and $7 \cdot 5$ (Fig. $3 b$ ) the redox potentials maintained by sulphide, prior to the introduction of dithionite, were around $-120 \mathrm{mV}$ and $-180 \mathrm{mV}$ respectively, and $\mathrm{H}_{2}$ evolution rates were minimal. These rates dramatically increased with the addition of dithionite and with the ensuing decrease in redox potential. Even though different concentrations of dithionite were needed to create identical redox potentials at the two $\mathrm{pH}$ values, maximal rates were observed in both cases when the redox was lowered to $-420 \mathrm{mV}$. It is concluded that at least up to $\mathrm{pH} 7 \cdot 5$, the low ambient redox potential imposed by dithionite is indeed the factor responsible for the acceleration of $\mathrm{H}_{2}$ evolution rates, and that a certain redox value, around $-420 \mathrm{mV}$, allows maximal in vivo activity.

The effect of redox potential on hydrogenase activity in cell-free extracts was measured at $\mathrm{pH} 7.5$, the optimum $\mathrm{pH}$ for the enzyme and also the cytoplasmic $\mathrm{pH}$ in many prokaryotes including cyanobacteria (Falkner et al., 1976; Padan et al., 1981). The hydrogenase-mediated $\mathrm{H}_{2}$ evolution was found to be dependent on redox potential in a pattern very similar to that of intact cells (Fig. 4). 


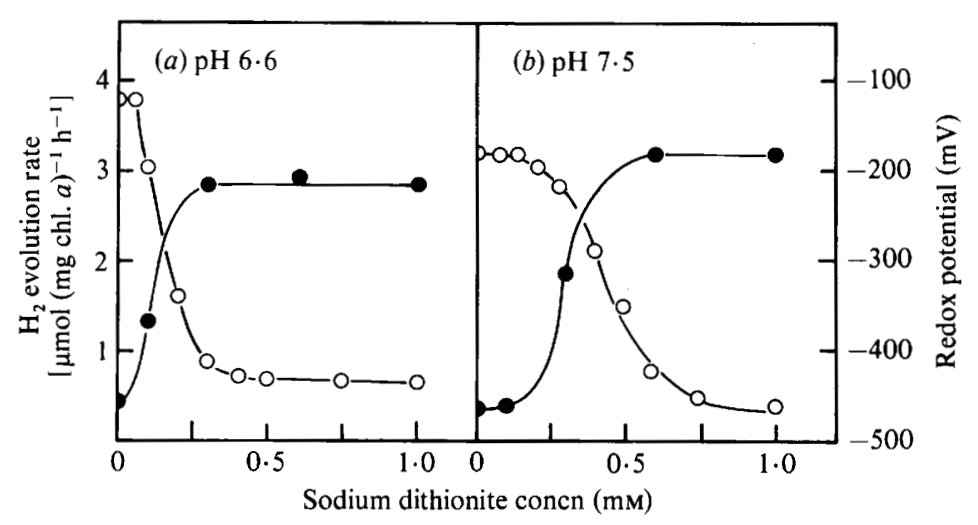

Fig. 3. Ambient redox potential $(O)$ and sulphide-dependent $\mathrm{H}_{2}$ evolution $(O)$ at $\mathrm{pH} 6.6(a)$ or $\mathrm{pH} 7.5$ (b). After the $\mathrm{N}_{2}$-flushing, cells were incubated in the presence of $3.5 \mathrm{~mm}-\mathrm{Na} \mathrm{S}_{2} \mathrm{~S}$ and various concentrations of sodium dithionite. $\mathrm{H}_{2}$ evolution was measured after linear rates had been established following the lag period.

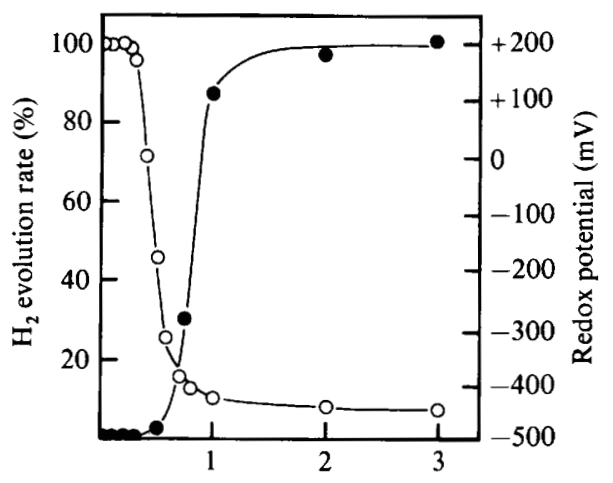

Sodium dithionite concn (mM)

Fig. 4. Redox potential $(\mathrm{O})$ and in vitro hydrogenase activity $(O)$ with different concentrations of $\mathrm{Na}_{2} \mathrm{~S}_{2} \mathrm{O}_{4}$ at pH 7.5. Maximal activity $(100 \%)$ was $1.2 \mu \mathrm{mol} \mathrm{H}_{2}$ evolved (mg chl. a $)^{-1} \mathrm{~h}^{-1}$.

\section{DISCUSSION}

Both anoxygenic sulphide-dependent $\mathrm{H}_{2}$ evolution and $\mathrm{CO}_{2}$ photoassimilation were shown to be dependent on photosystem I and to share the photosynthetic electron pathway up to ferredoxin. This common chain includes the plastoquinone site, since the quinone inhibitors DBMIB and DNP-INT inhibited both reactions. Furthermore, $\mathrm{H}_{2}$ evolution was restored in the DBMIB-inhibited system when reduced TMPD, which bypasses the block (Trebst \& Reimer, 1977), was added to the reaction mixture. Phosphorylation coupled to $\mathrm{H}_{2}$ evolution has been implicated, since the uncoupler FCCP accelerates $\mathrm{H}_{2}$ evolution (Belkin \& Padan, 1978a). This coupling site is most probably located at the quinone level, since FCCP has no enhancing effect on the reduced TMPD bypass to plastocyanin (Belkin et al., 1982). These results are in accordance with recent data implying a quinone in photophosphorylation or oxidative phosphorylation (Mitchell, 1979).

Dithionite markedly accelerated the rate of sulphide- and photosystem I-dependent $\mathrm{H}_{2}$ evolution in $O$. limnetica. It was however, incapable of replacing sulphide as an electron donor for anoxygenic photosynthetic $\mathrm{H}_{2}$ evolution and may thus only alleviate a rate-limiting step. This could occur at three levels in the pathway of the electrons from sulphide to $\mathrm{H}_{2}$ : the hydrogenase, the photosynthetic electron transport and the linkage between these two components. The level of the hydrogenase enzyme in these cells as measured in vitro was very 
high, and is therefore unlikely to limit the rate of sulphide- and light-dependent electron flow to $\mathrm{H}_{2}$ evolution in vivo. Whereas the enzyme could maintain a rate of $\mathrm{H}_{2}$ evolution equivalent to 18.6 and $140 \mu$ equiv. $\mathrm{e}^{-}(\mathrm{mg} \mathrm{chl} . a)^{-1} \mathrm{~h}^{-1}$ in $3 \mathrm{~h}$ induced or anaerobically grown cells respectively, the corresponding light-dependent activity was only $13-21 \%$. The electron transport rate through the pathway from plastoquinone to ferredoxin, which is common to both $\mathrm{CO}_{2}$ photoassimilation and $\mathrm{H}_{2}$ evolution, cannot include the rate-limiting step of the latter, since the electron flow culminating in $\mathrm{CO}_{2}$ fixation proceeds at least 18 times faster. Therefore it is concluded that the specific electron pathway to the hydrogenase, branching from the main transport chain, includes the rate-limiting step to $\mathrm{H}_{2}$ evolution. This step is most probably the one affected by dithionite.

Simultaneous measurements of the ambient redox potential imposed by dithionite on intact cells and the in vivo sulphide-dependent $\mathrm{H}_{2}$ evolution, as well as similar experiments with cellfree enzyme preparations, revealed that the lower the redox value, the higher the activity. The redox potential below which maximal $\mathrm{H}_{2}$ evolution rates were attained was around $-420 \mathrm{mV}$, similar to the midpoint potential of both the $\mathrm{H}_{2} / \mathrm{H}^{+}$couple and ferredoxin. Assuming that dithionite reduces both the external and the cytoplasmic redox potentials, it is suggested that the in vivo activity of the hydrogenase is modulated by the environmental redox potential. Dithionite had no effect on the rate of $\mathrm{H}_{2}$ evolution above $\mathrm{pH} 8.0$, when even in its absence similar rates of sulphide-dependent $\mathrm{H}_{2}$ evolution were measured. At this point the ambient redox potential maintained by sulphide was measured to be $-200 \mathrm{mV}$. It is suggested that, for an unknown reason, at this $\mathrm{pH}$ such a potential suffices to allow optimal flow of photosynthetically driven electrons to hydrogen.

The influence of redox potential on hydrogenase activity has been described for the purified enzymes of several bacteria (Chen, 1978; Van Dijk \& Veeger, 1981; Fernandez et al., 1982).In most of these cases, similarly to our results, maximal activity was reached below a certain potential, around -400 to $-450 \mathrm{mV}$. The importance of the redox state in the activity of ferredoxin has also been described (Carter et al., 1972; Cammack \& Christou, 1978) and control of photosynthetic enzymes by redox potential via the ferredoxin/thioredoxin system has been suggested (Buchanan, 1980).

Enhanced $\mathrm{H}_{2}$ evolution under highly reducing conditions was caused, in our case, by externally supplied dithionite. We suggest, however, that this effect mimics a physiological control mechanism, with $\mathrm{H}_{2}$ evolution acting as a valve regulating the intracellular redox environment. Such a role has been attributed to the nitrogenase-mediated $\mathrm{H}_{2}$ production of photosynthetic bacteria (Hillmer \& Gest, 1977) and to the hydrogenase-involving reactions of several heterotrophic bacteria (Adams et al., 1981) and eukaryotic algae (Kessler, 1974; Hallenbeck \& Benemann, 1979). The existence of such a redox-controlled 'switch' has recently been suggested in Proteus mirabilis, where electrons can be selectively channelled towards the reduction of either protons or other oxidants (Krab et al., 1982).

Since $\mathrm{H}_{2}$ evolution is very wasteful in terms of energy consumption, it is essential that it operates only when the system is over-reduced. Indeed, in $O$. limnetica, in the presence of ascorbate-reduced TMPD under anaerobic conditions, the rate of $\mathrm{H}_{2}$ evolution is very low (not shown). In the presence of sulphide, under similar conditions, the rate increases concomitantly with the lowering of the redox potential to $-200 \mathrm{mV}$. Addition of dithionite, yielding an ambient redox potential of $-420 \mathrm{mV}$, enhances the rate to the maximum. However, the rate of $\mathrm{H}_{2}$ evolution is always much lower than that of $\mathrm{CO}_{2}$ photoassimilation, although both reactions share a common segment of the electron transport chain. Furthermore, in the presence of $\mathrm{CO}_{2}$, $\mathrm{H}_{2}$ evolution is drastically inhibited, even in the presence of dithionite, implying that when $\mathrm{CO}_{2}$ photoassimilation takes place electron transport is safeguarded against leakage of electrons to $\mathrm{H}_{2}$. Similarly, in intact algal cells, light-dependent $\mathrm{H}_{2}$ production was observed only in the absence of $\mathrm{CO}_{2}$ photoassimilation (Kessler, 1974).

The ancient origin of the cyanobacteria, in the early Precambrian period (Schopf, 1974), implies that in the past they had to cope with an extremely reducing environment. Oscillatoria limnetica is one of the cyanobacterial species that retains a large part of the metabolic 
mechanism of its ancestors, namely the anoxygenic photosynthetic apparatus. The redoxcontrolled $\mathrm{H}_{2}$ valve may very well be another metabolic relic of this organism's evolutionary history.

The authors wish to thank Professor H. G. Schlegel (Göttingen University), Professor M. Avron (Weizman Institute of Science, Rehovot), Professor Z. Dori (Technion, Haifa) and Professor Z. Eisenshtat (Hebrew University, Jerusalem), for most stimulating and helpful discussions. The technical assistance of $B$. Arieli is most appreciated. This investigation was supported by a grant from the Niedersachsisches Ministerium für Wissenschaft und Kunst, Germany.

\section{REFERENCES}

Adams, M. W. W., Mortenson, L. E. \& Chen, J. S. (1981). Hydrogenase. Biochimica et biophysica acta 594, 105-176.

BelKIN, S. \& Padan, E. (1978a). Sulphide-dependent hydrogen evolution in the cyanobacterium Oscillatoria limnetica. FEBS Letters 94, 291-294.

Belkin, S. \& Padan, E. (1978 $b$ ). Sulphide-dependent hydrogen evolution and $\mathrm{CO}_{2}$ photoassimilation by the cyanobacterium Oscillatoria limnetica. In Hydrogenases: Their Catalytic Activity, Structure and Function, pp. 387-394. Edited by H. G. Schlegel \& K. Schneider, Göttingen: E. Goltze, K. G.

Belkin, S. \& Padan, E. (1983). Na-dithionite promotes photosynthetic sulphide utilization by the cyanobacterium Oscillatoria limnetica. Plant Physiology (in the Press).

Belkin, S., Arieli, B. \& Padan, E. (1982). Sulphidedependent electron transport in Oscillatoria limnetica. Israel Journal of Botany 31, 199-200.

BUCHANAN, B. B. (1980). Role of light in the regulation of chloroplast enzymes. Annual Review of Plant Physiology 31, 341-374.

Cammack, R. \& Christou, G. (1978). Characterization of iron-sulphur centers by E.P.R. spectroscopy: comparison with model systems. In Hydrogenases: Their Catalytic Activity, Structure and Function, pp. 45-56. Edited by H. G. Schlegel \& K. Schneider. Göttingen: E. Goltze K. G.

Carter, C. W., Jr, Krant, J., Freer, S. T., Alden, R. A., Sieker, L. C., Adman, E. \& Jensen, L. H. (1972). A comparison of $\mathrm{Fe}_{4} \mathrm{~S}_{4}$ clusters in high potential iron protein and in ferredoxin. Proceedings of the National Academy of Sciences of the United States of America 69, 3526-3529.

CHEN, J. S. (1978). Structure and function of two hydrogenases from the dinitrogen-fixing bacterium Clostridium pasteurianum W5. In Hydrogenases: Their Catalytic Activity, Structure and Function, pp. 57-81. Edited by H. G. Schlegel \& K. Schneider. Göttingen: E. Goltze K.G.

Cohen, Y., Padan, E. \& ShILo, M. (1975a). Facultative anoxygenic photosynthesis in the cyanobacterium Oscillatoria limnetica. Journal of Bacteriology 123, 855-861.

Cohen, Y., Yorgensen, B. B., PAdan, E. \& Shilo, M. (1975b). Sulphide-dependent anoxygenic photosynthesis in the cyanobacterium Oscillatoria limnetica. Nature, London 257, 489-492.

Falkner, G., Horner, F., Werdan, K. \& Heldt, H. W. (1976). pH changes in the cytoplasm of the blue-green alga Anacystis nidulans caused by

light-dependent proton flux into the thylakoid space. Plant Physiology 58, 717-718.

Fernandez, V. M., Munilla, R. \& Ballesteros, A. (1982). Influence of redox potential on the activity of Clostridium pasteurianum and Chromatium hydrogenases. Archives of Biochemistry and Biophysics 215, 129-135.

Hallenbeck, P. C. \& Benemann, J. R. (1979). Hydrogen from algae. In Photosynthesis in Relation to Model Systems (Topics in Photosynthesis, Vol. 3), pp. 33i-364. Edited by J. Barber. Amsterdam: Elsevier/ North Holland Biomedical Press.

Hillmer, P. \& Gest, H. (1977). $\mathrm{H}_{2}$ metabolism in the photosynthetic bacterium Rhodopseudomonas capsulata: $\mathrm{H}_{2}$ production by growing cultures. Journal of Bacteriology 129, 724-731.

KeSSLER, E. (1974). Hydrogenase, photoreduction and anaerobic growth. In Algal Physiology and Biochemistry, pp. 456-473. Edited by W. D. P. Stewart. London: Blackwell Scientific Publications.

Krab, K., Oltman, L. F. \& Stouthamer, A. H. (1982). Linkage of formate hydrogenlyase with anaerobic respiration in Proteus mirabilis. Biochimica et biophysica acta 679, 51-59.

MaCKINNEY, G. (1941). Absorption of light by chlorophyll solutions. Journal of Biological Chemistry 140, 315-322.

MitCheLL, P. (1979). Compartmentation and communication in living systems. Ligand conduction: a general catalytic principle in chemical, osmotic and chemiosmotic reaction systems. European Journal of Biochemistry 95, 1-20.

OREN, A. (1978). Oxygenic and anoxygenic photosynthesis in Oscillatoria limnetica. Ph.D. thesis, Hebrew University, Jerusalem.

OREN, A. \& PADAN, E. (1978). Induction of anaerobic photoautotrophic growth in the cyanobacterium Oscillatoria limnetica. Journal of Bacteriology 133, 558-563.

Oren, A., Padan, E. \& Avron, M. (1977). Quantum yields of oxygenic and anoxygenic photosynthesis in the cyanobacterium Oscillatoria limnetica. Proceedings of the National Academy of Sciences of the United States of America 74, 2152-2156.

Oren, A., Padan, E. \& Malkin, S. (1979). Sulphide inhibition of photosystem II in cyanobacteria (bluegreen algae) and tobacco chloroplasts. Biochimica et biophysica acta 546, 270-279.

PADAN, E. (1979). Impact of facultatively anaerobic photoautotrophic metabolism on ecology of cyanobacteria (blue-green algae). In Advances in Microbial 
Ecology, vol. 3, pp. 1-48. Edited by M. Alexander. New York: Plenum Press.

Padan, E., Zilberstein, D. \& Schuldiner, S. (1981). $\mathrm{pH}$ homeostasis in bacteria. Biochimica et biophysica acta 650, 151-166.

Schopf, J. W. (1974). Paleobiology of the Precambrian: the age of blue-green algae. In Evolutionary Biology, vol. 7, pp. 1-43. Edited by T. Dobzhansky, M. K. Hecht \& W. C. Steere. New York: Plenum Press.

Trebst, A. \& ReImer, S. (1977). Reversal of the inhibition of photosynthetic electron flow in the chloroplasts by an internal TMPD bypass. Photosynthetic Organelles, Special Issue of Plant and Cell Physiology, 201-209.
Trebst, A., Wietoska, H., Druber, W. \& Knops, H. J. (1978). The inhibition of photosynthetic electron flow in chloroplasts by the dinitrophenylether of bromo- or iodonitrothymol. Zeitschrift für Naturforschung 33c, 919-927.

TRÜPER, H. \& SChlegel, H. G. (1964). Sulphur metabolism in Thiorhodaceae. I. Quantitative measurements on growing cells of Chromatium okerii. Antonie van Leeuwenhoek 30, 225-238.

VAN DiJK, C. \& VeEger, C. (1981). The effects of pH and redox potential on the hydrogen production activity of the hydrogenase from Megasphaera elsdenii. European Journal of Biochemistry 114, 209219. 